\title{
Financial Innovation Boosts the Construction of the Belt and Road Initiative
}

\author{
Xiaobin Lin ${ }^{1, ~ a ~}$ \\ ${ }^{1}$ State Grid Energy Research Institute Co.,Ltd, State Grid Corporation of China, Beijing 102209, \\ China \\ alinxiaobin20062006@126.com
}

Keywords: The Belt and Road Initiative; financing; mutual benefit and win-win; financial innovation

Abstract: The Belt and Road Initiative has triggered the upsurge of foreign direct investment in many countries. Due to the particularity of countries along the Belt and Road, the financial development and innovation are necessary. Based on the great demand for financial services, this paper analyzes the financing problems faced by enterprises in the construction of projects on the B\&R countries, and the necessity of financial innovation. Finally, from the principles that should be followed, models, and products, it is proposed to promote financial innovation and financial development so as to ensure the implementation of the B\&R strategy.

\section{Introduction}

As the Chinese economy has entered the "new normal", the comparative advantage of rapid growth is declining. The external unfavorable environment such as sluggish domestic demand and weak external demand will still restrict the expectations of rapid growth in the next few years. The "One Belt and One Road" strategy was put forward under the circumstances of overcapacity in domestic production, an urgent need to change the mode of development, economic decline in developed countries, and continued weakness in external demand. Under the circumstances of overcapacity in domestic production, an urgent need to change the mode of development, economic decline in developed countries, and continued weakness in external demand, the "One Belt and One Road" strategy was put forward to optimize economic structure and industrial layout, achieve stable economic growth, expand China's strategic space, and promote regional stability and prosperity. Within a long period of time, the "One Belt and One Road" region will become a key international economic cooperation area for China. For enterprises, investing in "Belt and Road" countries and regions will help expand new profit margins and maintain development. For the country, through the investment activities of enterprises, not only can the domestic surplus production capacity be transferred and the industrial layout can be optimized, but also the resources, investment returns, and international status can be obtained, so as to gain comprehensive benefits.

Although there are many positive points, the practical problems are obvious. Overseas investment is an activity with large demand for funds, long duration and high risks. The "One Belt and One Road” along the route are mostly underdeveloped countries and regions where the level of 
economic development is low and the country's political risks are relatively high. The investment environment is far from that of developed countries such as Europe and the United States. It involves multi-faceted capital entities at home and abroad with different funds, participation and withdrawal of nodes at different times. Capital operation and management are very difficult. Efficient finance can provide guarantee for overseas investment. The lag in the development of financial markets and the absence of effective financial services are likely to hinder the implementation of the "One Belt and One Road” strategy.

\section{Financing Problems Faced by Enterprises Participating in the Construction of "Belt and Road"}

The proposal of the "One Belt and One Road" strategic concept provides new opportunities for countries along the route to development. It meets the common needs of countries along the route. However, strategic practice also raises many new challenges for the financing of Chinese companies.

\subsection{The Financing System of the Countries Along the "Belt and Road" Lags behind, The Capital Gap is Outstanding, and the Market Insecurity Factors and Risks are More Obvious.}

Most of the countries along the "One Belt and One Road" are developing countries, and their aspiration to economic development and social development is strong. However, the financial strength of these countries is not strong, the guarantee capacity is insufficient, and capital funds for project construction are seriously insufficient, which is an important factor that restricts the company's international business development in the region. The debt burden of some countries' governments is heavy. For instance, the ratio of foreign debt to GDP in countries such as Kyrgyzstan, Ukraine, Georgia, and Mongolia exceeds 100\%. At the same time, after the global financial crisis, international financial institutions have significantly reduced financing support for large-scale public projects, especially in developing countries that lack open and transparent business environment and international prevailing market rules. In the course of carrying out international business, enterprises will also face many kinds of risk issues such as political risks, security risks and economic risks. The uncertainties faced by companies in expanding their businesses and investing will increase.

\subsection{Infrastructure Investment is a Field with High Strategic and Sensitive Nature. In the Process of Outbound Investment, It Faces Relatively Strict Domestic and Foreign Governments' Approval and Supervision Policies.}

The State-owned Assets Supervision and Administration Commission of the People's Republic of China has stepped up efforts to audit the investments of non-primary overseas businesses of central SOEs, requiring that SOEs in principle not engage in non-primary investment projects overseas. Some countries along the route are wary of Chinese state-owned enterprises entering basic industries such as electricity and transportation, and set up trade and policy barriers. Foreign investment of Chinese enterprises adopts an investment permit examination and approval system and foreign exchange control of "gradual approval and limit management". The examination and approval procedures are cumbersome and complicated, and the time for external approval and filing is long, supervision is excessive, and the protection mechanism is not perfect. Strict, cumbersome, and inefficient approvals have often caused companies to miss the opportunity to acquire M\&As overseas, which has, to some extent, reduced the efficiency of their overseas investment activities. 


\subsection{Funds for Infrastructure Construction Have Huge Demand and Long Recovery Period, Lack of a Reliable and Stable Profit Model.}

The construction and improvement of infrastructure along the "One Belt and One Road" area requires a lot of capital investment. It is estimated that the national infrastructure investment demand along the "One Belt and One Road" 2016-2020 will be at least US\$10.6 trillion. Among them, the investment demand of countries alongside China is about 1.4 trillion US dollars. The profitability of infrastructure investment mainly comes from three aspects, one is user payment, the other is the arrangement of funds for payment due to the improvement of infrastructure revenues, and the third is the increase in commercial value of surrounding areas due to the improvement of infrastructure. There are certain risks in these three profit models. For the constructors and operators of infrastructure, the user payment model has a lower-than-expected market operation risk. In economically underdeveloped regions, market development is less likely than expected. The mode of payment of fiscal funds is subject to the overall financial capacity of the host country. Many countries along the "One Belt and One Road" have serious fiscal deficits and a high risk of debt default. The risk of commercial appreciation in the surrounding areas lies in the land system of the host country. For countries with private ownership of land, the surrounding land does not necessarily provide for the development of infrastructure construction operators, third-party development benefits are not necessarily shared with them. In reality, the debt default rate of the national infrastructure along the "One Belt and One Road" is very high, some international consulting agencies have even included some countries as high-risk debtors.

\subsection{There are Few Sources of Financing, Mainly Bank Loans, and there are Fewer Financing Options for the Project.}

At present, the main sources of financing are bank loans, and bank loan funds account for a relatively high proportion, which easily leads to the conversion of financing risks to bank risks. Bank loans are still the main source of funds for overseas mergers and acquisitions by Chinese companies. "Insurance foreign loans" are commonly used by Chinese companies. The commercial bank loan structure model is relatively single, basically based on the long-term loan financing based on CITIC Insurance underwriting. If CITIC Insurance cannot cover or exceed the coverage period of CITIC Insurance, the project will be difficult to continue.

\subsection{Compared with Overseas Financial Institutions, the Financing Costs Provided by Domestic Institutions are High.}

The cost of development and policy bank credit funds in China is still relatively high compared with the developed countries in the world. At present, China Development Bank's corporate lending rate is the basic interest rate, the medium- and long-term lending rate for 1 to 5 years is $4.75 \%$, and the medium- and long-term lending rate for more than 5 years is 4.9\%. China Exim Bank's "two-beneficial" lending rate is relatively low, ranging from $2 \%$ to $3 \%$, but it is subject to strict approval and requires higher qualifications for loan companies and projects. Domestic commercial bank guarantees are flexible and offer more options. However, the cost of financing is higher than that of policy banks. For example, the interest rate for corporate loans of Chinese banks is about 1.3 times the benchmark interest rate. In addition, companies that deal with domestic bond financing and equity financing also face high financing costs. 


\section{Demand for Financial Innovation under the Belt and Road Initiative}

There is a huge demand for funds for enterprises to participate in the construction of countries and regions along the "One Belt and One Road". Most of these countries and regions are underdeveloped countries. The development of financial markets is lagging behind. The financing system is lagging behind, with a single channel and high costs. Therefore, the existing financial support cannot meet the needs of Chinese companies and needs financial innovation.

\subsection{To Carry Out Bilateral and Multilateral Cooperation and Integrate the Development Resources of Countries Along the Route, Requires Financial Innovation.}

The economic development of countries along the "One Belt and One Road” is uneven, and the distribution of financial resources and natural resources is not matched and unbalanced. There are 19 high-income countries, 22 upper-middle-income countries, 20 lower-middle-income countries, and 3 low-income countries. The richness and variety of resource endowments in countries along the route vary greatly, and resources complement each other. The projects of Chinese companies in the countries are mainly focused on energy resource development and infrastructure construction projects. Enterprises in different levels of development and resource endowment countries to carry out project cooperation, the project's market prospects and risk status are different, so the financing conditions facing are also quite different. Through financial innovation, we can strengthen the integration of financial resources and advantageous resources in all regions. In this way, it can realize the interoperability of the entire region and achieve mutual benefit and win-win.

\subsection{Launch Multilateral Cooperation and Introduce International Financial Resources to Participate in the Construction of the "Belt and Road", Requires Financial Innovation.}

Most of the projects that China participates in countries along the route are Chinese-funded financial institutions as the sole contributors or main contributors. Companies alone bear a lot of financing pressures and risks. Overseas governments and institutions have less financial participation and support. From the perspective of joint development and sharing of risks, the introduction of third-party financial resources is imperative. International financial resources mainly include the following types. First, multilateral or regional development finance, such as the World Bank's International Bank for Reconstruction and Development (IBRD) loans and IDA loans, ADB loans, Asian Infrastructure Investment Bank (hereinafter referred to as “Asian Investment Bank") loans. The second is sovereign wealth funds, which are official investment funds established by a national or regional government. Sovereign wealth funds usually pay more attention to returns rather than liquidity. Therefore, compared with traditional foreign exchange reserves, they have higher risk tolerance capabilities and can be used as an important financing channel for financial innovation. The third is multinational institutional investors include insurance companies, pension funds, and investment funds that specialize in infrastructure investment. Most of these institutional investors are financial investors of infrastructure projects. They mainly seek to participate in projects through early stages to achieve a reasonable return on funds, and usually do not participate in the project operations. Usually, the better the expected return of the project, the easier it will be for multinational institutional investors. To mobilize these various types of resource channels, we must take into account the concepts of innovation, openness, coordination, and sharing, fully consider its advantages and appeals, and innovate financing methods to achieve mutual benefits and win-win results. 


\subsection{To Strengthen Business Cooperation and Information Sharing, and to Realize the Mission of Going Abroad, Requires Innovative Financing Mechanisms and Models.}

In the process of building the "One Belt and One Road", it is difficult to resist the risks of overseas politics and economy if companies go out and fight each other. In the "going out" process, there must be pathfinders and advance teams. These are important ways to reduce risk. For example, the overseas park model and the bank-enterprise model that are explored in practice help to achieve international industrial complementarity and capacity cooperation and form a joint force. The accumulation of industrial resources also urgently needs the supporting support of financial resources, and innovation is indispensable.

\subsection{To Tap Potentials, Integrate Internal Resources, And Jointly Support Enterprises to Participate in The "Belt and Road Initiative", Requires Innovative Financing Models and Tools.}

At present, there are policy-based financial institutions, Commercial financial institutions, and Special investment fund that can provide financing service for the "One Belt and One Road". To carry out financial innovation, it is necessary to fully rely on existing domestic financing channels. At the same time, it also should combine the stages of economic development, special political conditions, and the characteristics of resource and labor gathering of various countries along the route. Companies also need to refine their international business types, effectively integrate the characteristics of international business into innovation activities. Thus, financial products could be innovated and channels for raising funds be provided to meet the diversified and multi-level needs of project investment entities.

\section{Suggestions of " Belt and Road" Financial Innovation Development}

The realization of financial innovation is of great significance for enterprises to participate in the construction. Therefore, as the China domestic financial system is gradually being perfected, the use of financial innovation as the most dynamic force in promoting financial development will realize the financial needs of enterprises and promote the balance between supply and demand for financial services. Financial innovation can be achieved in the following four aspects.

\subsection{Adhere to Common Development and Sharing}

Financial innovation needs to follow the principle of common business cooperation. A community of interests that work together, share risks, and share benefits should be built. At the same time, it also needs to use market forces to maximize the mobilization of resources and ensure sustainability. In the phase of negotiation, a mechanism for the negotiation of cooperation among all countries, state-owned enterprises, and financial institutions needs to be established. On the basis of equality and mutual benefit, all parties should discuss cooperation plans and regional development plans, and unify development goals. In the phase of joint construction, through the cooperation of all parties, the government and market forces will be effectively connected to provide long-term and sustainable financial support for project construction by mobilizing all resources and using global funds. Central enterprises of China and Chinese-funded financial institutions should take the lead in actions to provide operational and sustainable development plans and structures. Development results will be shared by all parties through joint commerce and cooperation. 


\subsection{Use Local Capital Markets to Promote the Networking of Financial Institutions}

A networked cooperation pattern of interconnection, benefit sharing, and risk sharing can be built by institutional mutual establishment, financial service interconnection, financial infrastructure communication, exchanges and cooperation among financial regulatory authorities, etc. Due to the operating mode, business philosophy and financing conditions of financial institutions in developed countries, it is difficult to fully meet the needs of countries along the "One Belt and One Road". Therefore, it is necessary to promote the networked layout of financial institutions and financial services. Countries along the route should work together to effectively mobilize domestic and international resources and provide long-term and reliable financial support for the construction.

\subsection{Adopt a Differentiated Investment and Financing Strategy in Light of Local Conditions}

The countries and regions along the "Belt and Road" are quite different in political, economic, and cultural aspects, and the risks faced by investment vary greatly. Therefore, investment strategies should be formulated according to different countries and different investment business categories. First, differentiated financing methods need be adopted for countries with different risk types. For those with low risk, an investment and financing framework that focuses on market-oriented investment and financing can be built and supplemented by development financial institutions. For medium-risk countries, a framework for investment and financing that emphasizes both market-based finance and development finance should be built. If the risk level is high, a framework focusing on development financial institutions should be established and supplemented by market-oriented investment and financing. Second, different types of international business use different financing methods. According to the characteristics of different businesses and the needs of actual projects, specific financing models should be adopted.

\subsection{Model Innovation}

Using a combination of multiple financing tools to develop innovative financing models. Explore overseas financing through PPP and overseas asset collateral. Innovate overseas business financing models with a combination of financing instruments such as internal foreign loans, bridge financing, syndicated loans and bond financing. Make use of the advantages and characteristics of the PPP model to form a development model of "sharing benefits, sharing risks, and cooperation in the entire process". Access to domestic bank financing and expand the source of corporate financing by the assets, equity pledges.

\section{Conclusion}

The "Belt and Road" region has its own particularities. Under the traditional financial system framework, the financial media can no tmeet the needs of the "One Belt and One Road" strategy. Sustainable development is inseparable from financial innovation. On the basis of adhering to the principle of common development and cooperation, the country's own financial resources along the route should be make full use of. To provide financial support for Chinese enterprises to participate, differentiated investment and financing strategies, innovative investment and financing models are needed to achieve mutual benefit and win-win results. 


\section{Acknowledgement}

This research was financially supported by the project of State Grid Science \& Technology Foundation, Research on Optimizing Technology of Company Operation Mode Based on Classified Supervision of State-owned Enterprises (B3670516A00500ZQ000000).

\section{References}

[1] Caballero R J, Farhi E, Gourinchas P. An Equilibrium Model of Global Imbalances and Low Interest Rates. American Economic Review, 2008, 98 (1), p358 -393.

[2] Morck, R., Yeung, B. and Zhao, M. "Perspectives on China's outward foreign direct investment", Journal of International Business Studies, 2008,39, p337 -350.

[3] Abdullahi D. Ahmed. Effects of Financial Liberalization on Financial Market Development and Economic Performance of the SSA region: An Empirical Assessment. Economic Modeling 2013(30), p261-273.

[4] Mendoza E Q, Quadrini V, Rios-Rull J. Financial Integration, Financial Development and Global Imbalances, Journal of Political Economy, 2009, 117 (3), p371-416. 